\title{
Social Capital and Turkish-German Academic Linkages
}

Yeşim KUŞTEPELI (https://orcid.org/0000-0001-9600-2892), Department of Economics, Dokuz Eylül University, Turkey; e-mail: yesim.kustepeli@deu.edu.tr

Sedef AKGÜNGÖR (https://orcid.org/0000-0002-5178-8948), Department of Economics, Dokuz Eylül University,Turkey; e-mail: sedef.akgungor@deu.edu.tr

Yaprak GÜLCAN (https://orcid.org/0000-0001-7779-8071), Department of Economics, Dokuz Eylül University, Turkey; e-mail: yaprak.gulcan@deu.edu.tr

\section{Sosyal Sermaye ve Türk-Alman Akademik Bağlantıları}

\begin{abstract}
This study investigates linking social capital aspect and transnationality of academia through networks via European Framework Programme (FP5, FP6, FP7) ICT projects in which i) Turkey is coordinator and Germany is partner, ii) Germany is coordinator and Turkey is partner, iii) both Turkey and Germany are partners. Social Network Analysis results depict that in European FP ICT projects where Turkey and Germany collaborated, social capital in Turkey increased. Transnational network linkages provided basis and opportunities for knowledge transfer, innovation networks, and formation of social capital. Further research will analyze social capital creation of the institutions in Turkey and Germany individually.
\end{abstract}

Keywords

: $\quad$ Social Capital, Academic Linkages, Social Networks, European Framework Programmes, ICT Sector.

JEL Classification Codes : O35, I23, O5.

\section{$\ddot{\mathbf{O} z}$}

Bu çalışma, i) Türkiye koordinatör ve Almanya'nın ortak olduğu, ii) Almanya'nın koordinatör ve Türkiye'nin ortak olduğu, iii) hem Türkiye hem de Almanya'nın ortak olduğu Avrupa Çerçeve Programı (FP5, FP6, FP7) BIT projelerinde ulusötesi akademik ağların sosyal sermaye yönünü araştırmaktadır. Sosyal Ă̆ Analizi sonuçları, Türkiye ve Almanya'nın işbirliği yaptığı Avrupa'daki FP BIT projelerinde, Türkiye'de sosyal sermayenin arttığını göstermektedir. Ulusüstü ağ bağlantıları, bilgi transferi, yenilik ağları ve sosyal sermaye oluşumu için temel ve firsatlar sağlamıştır. İleride araştırmalar, Türkiye'deki ve Almanya'daki kurumların toplumsal sermaye yaratımını ayrı ayrı analiz etmeyi planlamaktadır.

Anahtar Sözcükler $\quad$ : Sosyal Sermaye, Akademik Bağlantılar, Sosyal Ağlar, Avrupa Birliği Çerçeve Programları, BİT Sektörü. 


\section{Introduction}

The concept of social capital initially appeared in community studies emphasizing the importance of networks which provide the basis for trust, cooperation, and collective action developed over time (Jacobs, 1965: 281). Since then, social capital has been used to explain a wide range of social phenomena, in addition to the development of human capital, economic performance of firms, geographic regions and nations (Putnam, 1993: 40-1; Fukuyama, 1995: 90-2). The most common definition of social capital features social organizations, such as networks, norms and social trust that facilitate coordination and cooperation for mutual benefit (Putnam, 1995). Thus, the major three central elements of social capital are networks, norms of civic cooperation, and trust. Trusting societies not only have stronger incentives to innovate and to accumulate physical capital but are also likely to have higher returns to accumulation of human capital (Knack \& Keefer, 1997: 1251-5).

Social capital also refers to the nature and extent of participation in informal networks and formal civic organizations, including network access. Social capital is multifunctional and a valuable asset as it embraces essential factors of economic production and provides a basis for collective action within society (Glaeser et. al., 2002: 438-44; Mones et. al., 2015: 2). Ceteris paribus, communities with high stocks of social capital may be expected to be wealthier and better governed, because members of these communities are able to find good jobs, initiate projects that serve public interests, use existing resources more efficiently and respond to public concerns more promptly (Woolcock, 1998: 155-6).

There are at least two significant properties of social capital. First one is that it facilitates the flow of information about opportunities and choices otherwise not available and reduces the transaction cost for an organization to recruit appropriate individuals and for individuals to find appropriate organizations which can use their capital and provide rewards (Routledge \& Amsberg, 2003:168-9). In addition, social ties through social capital carry more valued resources and exercise greater power in organizational agents' decision making. Furthermore, social credentials and reinforcement explain why social capital works in instrumental and expressive actions not accounted for by forms of personal capital such as economic capital or human capital (Lin, 1999: 31-6).

The second crucial property of social capital is the existence of effective network relationships. Such network relationships bring individuals and groups together for a positive mutual reward. For example, social capital works as horizontal ties and combines heterogeneous groups of people with different backgrounds that otherwise would have never come into contact (Sabatini, 2009: 430-1).

Thus, in regard to the relationships of connections between actors at different levels, social capital has been categorized as bonding, bridging, and linking. In very general terms, bonding social capital refers to connections to people in close circles (family, relatives, etc.) whereas bridging social capital is defined as the connections to people in remoter circles (e.g. colleagues). Linking social capital is related to connections with people in power either politically, financially or institutionally (Dahal \& Adhikari, 2008: 3-4). While bonding and 
bridging social capital refer to horizontal social networks, linking social capital reflects how actors are vertically networked with institutional structures (Poortinga, 2012: 287-9). This study focuses on linking social capital with regards to academic linkages.

The aim of this study is to analyze research networks in academia with specific focus on information and communication technology (ICT) sector between Turkey and Germany in terms of European Framework Programmes. One of the main reasons of considering ICT sector is that ICT sector has been and is still a substantial driver of change in social capital and academic research. It has contributed to the internationalization of academics and growth of the research output through student portals, use of the Internet, digital libraries, etc. (Larsen \& Vincent-Lancrin, 2006). Researchers are able to collaborate and share ideas and knowledge across the world without travelling, just through e-mails. Easier and quicker access to information, datasets and recent research decreased the cost of academic R\&D and led to the increase in research output. Another reason that this study focuses on ICT sector is that it is a knowledge-intensive technology field in which Turkey and Germany collaborate in the European Framework Programmes. Turkey and Germany collaborated in 9 ICT projects in FP5, 48 in FP6 and 60 in FP7 Programme. All of these numbers of projects are the highest in the total collaborative ICT projects of Turkey and Germany (Gülcan \& Aldemir, 2017). Furthermore, German organizations have the highest share in terms of participating organizations in almost all ICT academic networks with Turkish participation in FP5 to FP7 (Peschkov \& Pyka \& Heller-Schuh, 2017: 56-7).

The rest of the paper is organized as follows: section 2 provides the conceptual framework; section 3 gives the background for Turkish-German academic network. Data and method and the results of the analysis are explained in sections 4 and 5 respectively. Finally, section 6 concludes.

\section{Conceptual Framework}

In a developing economy with increasing complexity, social capital is valuable if networks are able to soften the communication constraint without reducing inclusiveness. Gains from participation in networks can be high also in personalized exchange settings as long as the communication capacity in a social network is high (Lin, 1999: 38-40). Social networks constitute fertile grounds for nurturing trust and shared values that reduce monitoring costs and facilitate transactions. Repeated interactions among group members foster information diffusion that raises reputations' relevance. If social capital is defined as a player's reputation for being cooperative within a social network (Putnam, 1993: 41-2), an individual's qualities have to be known by others and this knowledge constitutes an asset that influences this individual's stream of benefits over time. An understanding of differences in network characteristics is crucial in order to determine the economic value of social capital created in these networks which may also include "transnational linkages" (Annen, 2003: 452-5).

Transnational linkages include various kinds of interactions between economic agents such as vertical organizational linkages to international organizations/actors, transfer 
of expert knowledge, and horizontal organizational linkages to foreign actors. In pursuing self-interest, economic agents incorporate knowledge by consulting various knowledge holders, by engagements in foreign training or transnational networks and, more fundamentally, through the universality of scientific knowledge. These actors establish bilateral or multilateral cross-national connections in networks with innovators and organizations based on their own need to reach knowledge, effective practices, tactics, discourses, or organizational structures (Wang \& Hosoki, 2016: 4-5).

In terms of effective transnational linkages and achievement of social capital, networks form a strategic response to the challenges and opportunities facilitated by the globalization of capital and by technological changes, particularly the expansion of information and communication technologies (ICTs). In comparison to other relationships between organizations, they have the potential to provide a more flexible and nonhierarchical means of exchange and interaction which promises to be more innovative, responsive and dynamic. These supposed advantages of networks provide development opportunities to industry with its comparative advantage over the state and market. Particularly, the main functions of knowledge networks include the collective production, accumulation and dissemination of knowledge and the enhancement of the participants' resource base and political status (Henry et. al., 2004: 845).

Rapid technological and economic developments and complex nature of innovation processes require special efforts for innovation policies. Through external networking, it is possible to reach new technologies and information by boundary spanning activities. In this sense, networks with long-term relationships are essential to innovation as they offer a competitive advantage in terms of innovations, especially in industries characterized by short product cycles and rapid market changes. Thus, networks and particularly innovation networks are structures and social communication processes through which information and knowledge can easily be exchanged (Cooke, 1996: 162; Frenken, 2000: 262; Pyka \& Buchmann, 2011: 469-70). Innovation networks are found to consist of various layers from regional to national/international and higher levels; and these layers seem to complement rather than to substitute each other (Tödtling, 1999: 694; Zander, 1999: 200).

Innovation networks have crucial impacts on the development and integration of economies. Saxenian (2006) stresses the role of individuals which transfer competences from the core to the periphery regions by using the core/periphery model of economic development. These commuting entrepreneurs immigrate to core regions to be academically trained and to create their first business and social networks in core regions. Then, they either stay in the core regions or return to their home periphery regions. In either case, they help the development of prolific network structures for knowledge and economic transactions and significantly push development in their periphery regions. With increasing knowledge intensity and transformations of the world economy, commuting entrepreneurs can clearly mitigate this delaying mechanism and support in an increasing number of regions worldwide to manage catching up processes more successfully. Saxenian's approach reflects the new characteristics for knowledge-based economies, namely cheap transportation costs and easy coordination over long distances by means of modern information and communication 
technologies. According to Avnimelech and Teubal (2008: 155-6), the industrial policy of a periphery region focusing on catching up needs to create multi-agent network structures which support the entrepreneurial creation of innovation networks which then relate core and periphery regions.

Various forms of network connections between innovative sub-national regions in different countries, hence the transnational innovation networks emphasize the significance of external networks that contribute to innovative activity with the movement of knowledgeable individuals. These transnational networks encompass the formation of transnational technical communities by mutually beneficial connections and the circulation of people, capital, technologies and ideas. Thus, innovation extends beyond the strictly technical or technological realm and is clearly embedded in broader social and historical processes. Transnational networks are shaped by the political and corporate structures of the global economy in a mutually constitutive manner. The need for these knowledgeable individuals to circulate comes from the demand in industrial economies for embodied technological skills and knowledge. It is not only that they possess knowledge for the replication of existing innovative activity, but they also engage in networks facilitating the external renewal and reworking of practices that define innovation (Coe \& Bunnell, 2003: 447-50).

The structure of an innovation network is very important for it to work well and produce innovations. Knowledge mobility, innovation appropriability and network stability are the crucial characteristics of innovation networks (Dhanaraj \& Parkhe, 2006: 664). Knowledge mobility is the convenience of sharing, acquiring and deploying knowledge within the network. The higher the knowledge mobility the greater will be the performance of innovation network and of an organization in the network. Innovation appropriability is the ability of the innovator to capture the returns generated by an innovation. Obviously, innovation activities will be stimulated in a network where innovation appropriability is guaranteed. Finally, network stability is the dynamic stability meaning that the network grows at a positive rate, taking into account the entry and exit of organizations. No doubt, a stable innovation network will create higher returns for the network and its members.

While the analysis on innovation networks applies well for the knowledge transfer at the organization and regional level, additional factors play role at the national level. Literature documents that there are asymmetries in technological and production capabilities of the countries. Such asymmetries demand some modifications in the analysis of innovation networks across countries in different stages of development. While organizational internal research and development $(R \& D)$ activities are important, no single organization can keep pace with the current speed of technological development in isolation and accessing external knowledge and actively engaging in international innovation networks becomes crucial (Pyka \& Scharnhorst, 2010: 7-8). Several large developing and emerging countries like Turkey, Malaysia, Brazil, India or China diversified their economies and initiated a technological catch-up process by the help of international investment, migrant diasporas and innovation networks. To become a dynamic knowledge-based economy in the world 
and to create more and better jobs, the mobility of knowledge, which emphasizes the role of cultural diversity and interactive learning, becomes an important issue.

In the light of the above discussions, the hypothesis of this study is that through transnational linkages in European Framework Programme networks and collaboration with Germany in ICT thematic area, Turkey has benefitted from opportunities for knowledge transfer and innovation networks, and most importantly she has increased her "linking" social capital. This hypothesis is tested initially with descriptive statistics and then with Social Network Analysis data metrics and maps.

\section{Turkish-German Academic Network}

This paper focuses on research innovation networks and social capital between Turkey and Germany in academia. Undoubtedly, academia has a special importance in terms of a nation's development of all kinds (economic, social, political, etc). Research and Development in academia fosters advances and innovation in industrial sectors of the economy and thus triggers social capital, growth and development. Academic research and development is undertaken in the higher education sector, including universities and research centers that have close links with higher education institutions. One of the main outputs of academic R\&D is scientific articles. There has been a massive increase of academic R\&D in the world through the years. Between 2000 and 2010, the number of researchers in $\mathrm{R} \& \mathrm{D}$ in the world increased by $18.38 \%$ on average. About 1.5 million scientific and technical journal articles were published globally in 2006, a $44 \%$ increase compared to the 2.2 million articles published in 2013 (World Bank, 2013). The emergence of knowledge economy has been one of the main drivers of this growth in academia sector. In addition, increased international academic mobility and collaboration have led to the growth of internationally coauthored scientific articles (Vincent-Lancrin, 2006). Academic mobility, mostly geographical movements for professional activities such as research stays, guest professorships and conference travel play a key role in maintaining a strong research capacity but also in the long term development of transnational networks within and beyond the academy. Scientific practice is thus understood as a network-building and social capitalenhancing process (Jöns, 2007: 98).

This study investigates the linking social capital aspect and transnationality of academia through academic networks in ICT sector via FP5, FP6, FP7 projects in which

- Turkey is the coordinator of the project and Germany is a partner,

- Germany is the coordinator of the project and Turkey is a partner,

- Both Turkey and Germany are partners in the project.

The case of Turkey and Germany is of interest for several reasons. First of all, the history of Turkish-German relations entails cases in terms of knowledge transfer and collaboration through innovation Networks, fostering catching-up processes as well as crossborder mutual learning. Turkey and Germany are two nations with various historical, political, economic, social and cultural ties. Although Turkey's innovation activities are not 
still at desired levels, in the last decade, she succeeded to be a dynamic emerging economy with diversified export portfolio into more advanced sectors and advances in academia sector by the foundation of several new universities and research centers.

Within the long history of Turkish-German relations of various kinds, the exchange of knowledge can be said to start with the establishment of the Germany Military Commission (GMC) in 1882, which helped the Ottoman army in the reorganization and the introduction of the modern military exercises. Since then, German academicians and educators helped in increasing the effectiveness of the higher education system, establishing and/or developing academic organizations (such as departments and universities) and create manifold academic links between both countries (Gülcan \& Aldemir, 2017: 336).

In the early twentieth century, many German schools and hospitals were built in Istanbul. In 1913, almost 1300 Ottomans (students and foreign workers) lived in Berlin. In the first half of 1940s, Turkey accepted German emigrants who fled from the Nazi regime. These German scholars contributed remarkably to Turkey's scientific and academic studies. Their heritage includes the reformation of higher education, establishment of new faculties and institutions, and education of Turkish scholars. Today, these emigrants still play an important role in the ongoing modernization of Turkey (Pyka et. al., 2017: 3).

Turkish-German relations intensified with the Contract of Labor Migration signed by the two countries in 1961. This agreement leads to large-scale emigration from Turkey to Germany and made Turks the largest group of the immigrants reaching almost three million in the 1980s (İçduygu, 2012: 12). This large level of migration between Germany and Turkey has also significantly contributed to the knowledge exchange and social networks between both countries. In 2009, Germany and Turkey jointly celebrated 50 years of bilateral development cooperation. During this period, more than $€ 4.3$ billion of funding has been provided to Turkey from Germany in the form of loans and grants. Meanwhile, economic cooperation is continuously expanded by various bilateral research and technology projects. The Federal Ministry of Education and Research of Germany implements and conducts scientific initiatives with Turkey, including cooperation with the Scientific and Technological Research Council of Turkey (TUBITAK) (Kustepeli et.al, 2013: 29).

The role and effect of Germany in Turkish higher education system is unignorable. As a result of a long and effective historical collaboration between Germany and Turkey, currently, there is a multi-actor social network in academia sector; in addition to a high-level transfer of knowledge and economic integration. Gülcan and Aldemir (2017: 311-6) demonstrate that the network relations between Turkish and German institutions in the academia sector are strong and persistent, producing many academic project and patents.

In this regard, EU Framework Programmes (FPs) constitute a driving force for the formation of dynamic networks, in which, organizations involved in R\&D networking projects and their cooperation serve as a channel for knowledge spillovers (Güler \& Kara, 2011: $3-4)$. Turkey participated in the $4^{\text {th }}$ and $5^{\text {th }}$ FPs on a project basis and is regarded an associated country in the following Framework Programmes (FP6, FP7, Horizon2020). 
European Framework Programme being the main instrument of European research policy, has been conceived as an instrument of transnational collaborative research aimed at improving the international competitiveness of European industry, while at the same time strengthening EU cohesion (Güler \& Kara, 2011: 4-5; Heller-Schuh et. al., 2011: 17-18).

Thus, we aim to shed light to the development of social capital in Turkish and German ICT academics, through transnational linkages in social research networks in European Framework Programmes. The historical and intensive Turkish-German relationships bear a large potential for knowledge transfer and innovation dynamics which are thought to result in higher social capital and higher economic welfare in both countries.

\section{Data and Methodology}

The data used in this study is collected from the European Commission CORDIS website (<http://cordis.europa.eu/projects/home_en.html〉). For each Framework Programme (5, 6 and 7), after choosing the ICT thematic area, the projects in which Turkey and Germany collaborated are isolated and all the partner countries in these projects are individually listed. These projects are then classified according to the criteria that i) Germany is the coordinator and Turkey is a partner, ii) Turkey is the coordinator and Germany is a partner, iii) both Germany and Turkey are partners.

We first investigate the hypothesis of the study by descriptive statistics. Then we use Social Network analysis to further analyze the social capital formation in Turkey through collaboration in European FP ICT projects.

Social network analysis (SNA) is an effective method of visualizing network relations by means of determining places of and relations between different actors. In addition to the mapping of network ties, SNA approach provides graph metrics as statistical information, which demonstrates the quantity and structure of connection paths between these actors. This methodology elucidates the descriptive questions, such as degree measures, as well as the more complex question of function, such as centrality and clustering characteristics.

Among much statistical information that can be collected about the actors (nodes) in a network through SNA, the most widely used measures are centrality measures; namely, degree centrality, closeness centrality, betweenness centrality, eigenvector centrality and clustering coefficient.

Degree centrality refers to the number of direct links attached to other nodes in the network. The most successful node should have the highest number of relationships with the other nodes. The degree centrality is also interpreted in terms of the immediate possibility of a node for catching whatever is flowing through the network, such as an knowledge, money etc. Actors with high degree centrality are integrated stronger within a network with prominent collaborative experience and are assumed to have many advantages: to be highly visible, to easily receive or diffuse information, or to have better access to more resources. 
Having many connections and thus high degree centrality provides influence and power to a node, but the quality of the connections is also important. Connections to actors who are themselves well connected (high degree) will provide actors with more influence than connections to poorly connected (low degree) actors. Degree centrality is calculated as follows where $x$ is the number of links that actor $i$ has with other actors, $j$, in the network:

$$
d_{i}=\sum_{j} x_{i j}=\sum_{j} x_{j i}
$$

The distance metric between all nodes in a network is defined by the length of their shortest paths. The lower the total distance of a node to all other nodes, the more central that node is. Closeness centrality takes into account the reachability of an actor and higher closeness centrality scores indicate short distances. Nodes with short distances from any other node (lower closeness centrality measures) can obtain or spread information within the network more efficiently than more distant ones. Assuming that information takes the shortest paths when spreading in a network, vertices that are at a short distance from any other are likely to receive them more quickly than more distant vertices. Closeness centrality is calculated as the reciprocal value of the geodesic distances (shortest paths measured as the number of steps/ties between two actors):

$$
c_{i}=\frac{(n-1)}{\sum_{j=1}^{n} d\left(n_{i}, n_{j}\right)}
$$

Betweenness centrality measure of a node within the network quantifies the number of times a node acts as a bridge along the shortest path between other nodes. It examines the role of actors according to their importance as an intermediary within the network. In this regard, betweenness centrality is interpreted as a measure of control of information flow, as actors lying on many shortest paths between actors, may act as gatekeepers without the necessity to maintain direct ties. Those actors, who are located on the shortest paths between many actors, therefore hold a key position for controlling the flow of information within the network (gatekeeper function). Betweenness centrality is the probability that the communication between the actors $k$ and $j$ goes via actor $i$. Therefore, the probability $b_{j k}$ for every pair $j$ and $k$ is calculated by dividing the amount of geodesics (i.e. shortest paths) $g_{j k}\left(n_{i}\right)$ between $j$ and $k$ that go via $i$ by the total number of shortest paths $g_{j k}$ between $j$ and $k$. These probabilities are then summed up for every pair of actors in the network:

$$
b_{j k}\left(n_{i}\right)=\frac{g_{j k}\left(n_{i}\right)}{g_{j k}}
$$




$$
b_{i}=\sum_{j<}^{n} \sum_{k}^{n} b_{j k}\left(n_{i}\right)
$$

Eigenvector centrality is also an important measure, which is directly and positively related with the degree centrality. Eigenvector centrality accords each node a centrality that depends both on the number and the quality of its connections by examining all nodes in parallel and assigning centrality weights that correspond to the average centrality of all neighbors; and is calculated as follows:

$$
\lambda c_{i}=\sum_{j=1}^{n} a i j c j
$$

We aim to demonstrate (linking) social capital formation increased in Turkey with her participation in FP5, FP6, and FP7 in ICT sectors and Germany as a strategic partner, by the use of SNA analysis. The position of Turkey in the European Framework Programmes in IICT sector will be determined by her position in the academic network. We expect that degree centrality, betwenness centrality and eigenvector centrality values for Turkey have increased and closeness centrality measure have increased.

\section{Results and Discussion}

For the aim of analyzing social capital formation and transnational linkages in Turkish-German research innovation networks in ICT sector, Turkish-German collaboration is analyzed in detail in terms of thematic areas in $5^{\text {th }}, 6^{\text {th }}$ and $7^{\text {th }}$ European Framework Programmes and considering the cases where Germany is the coordinator and Turkey is a partner, Turkey is the coordinator and Germany is a partner, and where both countries are partners in the project.

Table: 1

\section{Total Number of Turkey and Germany Collaboration FP5 Projects (1998-2002)}

\begin{tabular}{|c|c|c|c|c|c|}
\hline Thematic areas & $\begin{array}{c}\text { Germany Coordinator, } \\
\text { Turkey Partner }\end{array}$ & $\begin{array}{c}\text { Turkey Coordinator, } \\
\text { Germany Partner }\end{array}$ & Both Countries Partners & Total Joint Projects & \% Share \\
\hline ICT & 1 & - & 8 & 9 & 26,5 \\
\hline INCO 2 & 3 & - & 4 & 7 & 20,6 \\
\hline EESD & 1 & - & 6 & 7 & 20,6 \\
\hline GROWTH & 1 & - & 4 & 5 & 14,7 \\
\hline H. POTENTIAL & - & - & 3 & 3 & 8,8 \\
\hline LIFE QUALITY & 1 & - & 2 & 3 & 8,8 \\
\hline TOTAL & $\mathbf{7}$ & $\mathbf{0}$ & $\mathbf{2 7}$ & $\mathbf{3 4}$ & $\mathbf{1 0 0}$ \\
\hline
\end{tabular}

ICT: Information Society, INCO 2: International Collaboration, EESD: Energy, environment and sustainable development GROWTH: Growth, H. POTENTIAL: Human Potential, LIFE QUALITY: Life Quality. Source: Gülcan and Aldemir (2017).

During the FP5 period (1998-2002), Turkey and Germany collaborated in a total of 34 projects, where in 7 of these projects Germany was coordinator and Turkey participant; and 27 of them both countries participant in 7 different fields. Turkey did not coordinate any 
FP5 projects. Table 1 demonstrates that out of total 34 projects, ICT sector had the highest number of total joint projects of Germany and Turkey, with 26,5\% (9/34).

Turkish-German academic collaboration in FP6 reached to 220 projects with an increase of 5.5 folds in 15 different fields. The number of projects that Germany was the coordinator and Turkey partner increased six folds from 7 in FP5 to 42 in FP6. Turkey coordinated a total of 9 projects; and two countries acted as partners in 169 projects, which is again more than six folds. ICT sector ranks first in Turkish-German academic collaboration in FP6 (as in FP5) with a total of 48 projects where in 6 of these Turkey was a coordinator and Germany partner (Table 2).

Table: 2

Total Number of Turkey and Germany Collaboration FP6 Projects (2003-2006)

\begin{tabular}{|c|c|c|c|c|c|}
\hline Thematic areas & $\begin{array}{c}\text { Germany Coordinator, } \\
\text { Turkey Partner }\end{array}$ & $\begin{array}{c}\text { Turkey Coordinator, } \\
\text { Germany Partner }\end{array}$ & Both Countries Participants & Total Joint Projects & $\%$ Share \\
\hline ICT & 9 & 6 & 32 & 47 & 21,36 \\
\hline SUSTDEV & 9 & - & 34 & 43 & 19,55 \\
\hline NMP & 1 & - & 17 & 18 & 8,18 \\
\hline CITIZENS & 4 & 1 & 12 & 17 & 7,73 \\
\hline FOOD & 3 & - & 12 & 15 & 6,82 \\
\hline INNOVATION & 3 & - & 9 & 12 & 5,45 \\
\hline MOBILITY & 2 & 2 & 8 & 12 & 5,45 \\
\hline POLICIES & 1 & - & 11 & 12 & 5,45 \\
\hline SME & 3 & - & 7 & 10 & 4,55 \\
\hline COORDINATION & 1 & - & 7 & 8 & 3,64 \\
\hline LIFESCIHEALTH & 2 & - & 5 & 7 & 3,18 \\
\hline INCO & 2 & - & 5 & 7 & 3,18 \\
\hline INFRAST & 1 & - & 4 & 5 & 2,27 \\
\hline AEROSPACE & - & - & 5 & 5 & 2,27 \\
\hline SOCIETY & 1 & - & 1 & 2 & 0,91 \\
\hline TOTAL & 42 & 9 & 169 & 220 & 100 \\
\hline
\end{tabular}

LIFESCIHEALTH: Life sciences, genomics and biotechnology for health, SUSTDEV: Sustainable development, global change and ecosystems, INFRAST: Research infrastructures, COORDINATION: Co-ordination of research activities, INNOVATION: Research and Innovation, MOBILITY: Marie Curie Actions - Human resources and mobility, SME: SME activities, CITIZENS: Citizens and governance in a knowledge-based society, FOOD: Food quality and safety, NMP: Nanotechnologies and nano-sciences, knowledge-based multifunctional materials and new production processes and devices, AEROSPACE: Aeronautics and space, POLICIES: Development of research/innovation policies, SOCIETY: Science and Society, Source: Gülcan and Aldemir (2017).

Table 4 isolates the ICT sector in FP5, FP6 and FP7 and shows the share of Germany as a partner in Turkey's total participation in the Framework Programmes. In Seventh Framework Programme (FP7), Turkey and Germany continued to work together in academic projects and thus research networks. Table 3 shows that Turkish and German scholars collaborated in 17 fields in a total of 495 projects (corresponding to an increase of more than 2 folds). There are 15 projects where Turkey was the coordinator with Germany partner and there are 100 projects as Germany coordinator and Turkey partner. The number of jointly carried out projects with both countries' participant is 378 . With a total of 72 projects, ICT sector was again the field where Turkey and Germany collaborated the most among other fields. Of these 72 projects, in 6 of them Turkey was the coordinator and 11 of them Germany was the coordinator.

As a result, Turkish-German collaboration in European Framework Programmes increased from FP5 to FP6 and to FP7, with total joint projects of 34, 220 and 495, 
respectively. In addition, the ICT thematic area had the highest share among other fields in this collaboration.

\section{Table: 3}

\section{Total Number of Turkey and Germany Collaboration FP7 Projects (2007-2013)}

\begin{tabular}{|c|c|c|c|c|c|}
\hline & $\begin{array}{c}\text { Germany Coordinator, } \\
\text { Turkey Partner }\end{array}$ & $\begin{array}{l}\text { Turkey Coordinator, } \\
\text { Germany Partner }\end{array}$ & Both Countries Participants & Total Joint Projects & $\%$ Share \\
\hline ICT & 11 & 6 & 55 & 72 & 14,54 \\
\hline SME & 14 & 1 & 42 & 57 & 11,52 \\
\hline KBBE & 9 & - & 44 & 53 & 10,71 \\
\hline NMP & 4 & 1 & 37 & 42 & 8,48 \\
\hline ENV & 7 & 1 & 30 & 38 & 7,68 \\
\hline TRANSPORT & 10 & - & 27 & 37 & 7,47 \\
\hline SSH & 8 & 2 & 24 & 34 & 6,87 \\
\hline INFRAST. & 4 & - & 23 & 27 & 5,45 \\
\hline INCO & 8 & 1 & 17 & 26 & 5,25 \\
\hline PEOPLE & 9 & 3 & 12 & 24 & 4,85 \\
\hline HEALTH & 5 & - & 16 & 21 & 4,24 \\
\hline SIS & 3 & - & 14 & 17 & 3,43 \\
\hline ENERGY & 2 & - & 14 & 16 & 3,23 \\
\hline SEC & 3 & - & 9 & 12 & 2,42 \\
\hline SPACE & 3 & - & 8 & 11 & 2,22 \\
\hline REGIONS & - & - & 5 & 5 & 1,01 \\
\hline REGPOT & - & - & 1 & 1 & 0,20 \\
\hline TOTAL & 100 & 15 & 378 & 495 & 100 \\
\hline
\end{tabular}

SSH: Socio-economic Sciences and Humanities, ENERGY: Energy, SIS: Science in Society, PEOPLE: People, TRANSPORT: Transport, SEC: Security Research, HEALTH: Health, KBBE: Knowledge Based Bio-Economy, REGIONS: Regions of knowledge, SPACE: Space, ENV: Environment, REGPOT: Research potential of Convergence Regions, Source: Gülcan and Aldemir (2017).

In FP5, Turkey participated in 18 ICT projects in which Germany was a partner in 9 of these. Turkey participated in a total of $536^{\text {th }}$ Framework Programme ICT projects with Germany as a collaborator in 47. Germany's share in total Turkish participation in ICT projects increased from 50\% in FP5 to $89 \%$ in FP6. This number was slightly decreased in FP7 with $86 \%$.

\section{Table: 4}

The Share of Germany in Total Turkish Participation in FP5, FP6, FP7 in ICT Sector

\begin{tabular}{|c|c|c|c|}
\hline & FP5 & FP6 & FP7 \\
\hline German-Turkish Collaboration & 9 & 47 & 72 \\
\hline Total Turkish Participation & 18 & 53 & 84 \\
\hline Share of Germany & $50 \%$ & $89 \%$ & $86 \%$ \\
\hline
\end{tabular}

The analysis above demonstrates that Turkish-German collaboration in European Framework Programmes increased dramatically from FP5 to FP6 and FP7; referring to the fact that Germany has been a very crucial partner for Turkey in the European research arena. In addition, ICT thematic area was the area in which Turkish and German actors cooperated the most. The next step is to investigate the (linking) social capital formation in Turkey as a result of these transnational linkages that are expected to provide the basis and opportunities for knowledge transfer and innovation networks, especially in terms of the connections in these networks. 


\section{Linking Social Capital in Turkey via Social Network Analysis}

Figures 1, 2 and 3 present the network maps of total ICT projects where Turkey and Germany are participants in FP5, FP6, and FP7 respectively. All projects where Germany is the coordinator and Turkey is the partner, Turkey is the coordinator and Germany is the partner and both countries are partners are included in the SNA maps. Each node represents a country and all the nodes are of identical size regardless of their centrality measures.

\section{Figure: 1}

\section{SNA Map of ICT Projects in FP5 (Turkey and Germany are Participants)}

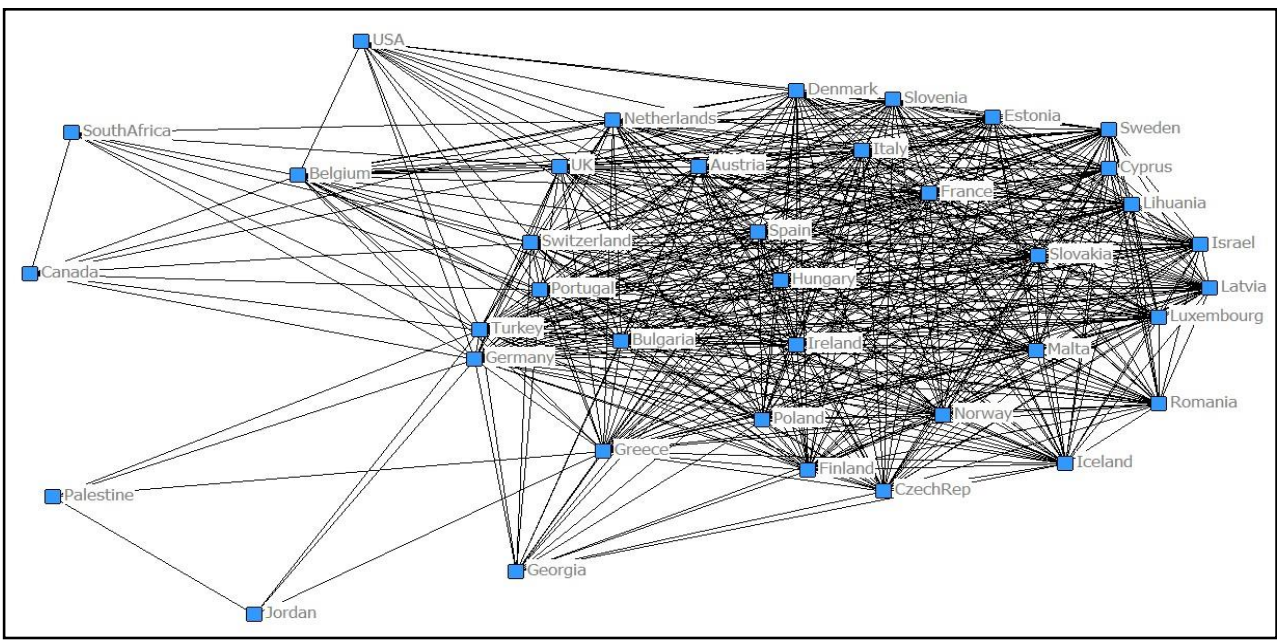

It can be observed from the maps that the networks get denser and the links between the countries increase as we move from FP5 to FP6 and to FP7. In addition, in FP5 Turkey and Germany are positioned at the left outer circle of the network but they move inside the network in FP6 with increased links. In FP7, both countries are part of the dense network, but still father from the center. This means that Germany and specifically Turkey increased their network relationships in the European research area from Framework Programmes 5 to 6 to 7. It is proposed that as the number of projects that they collaborated increased, knowledge transfers and spillovers took place which led to an increase in "linking" social capital in Turkey. 


\section{Figure: 2}

\section{SNA Map of ICT Projects in FP6 (Turkey and Germany are Participants)}

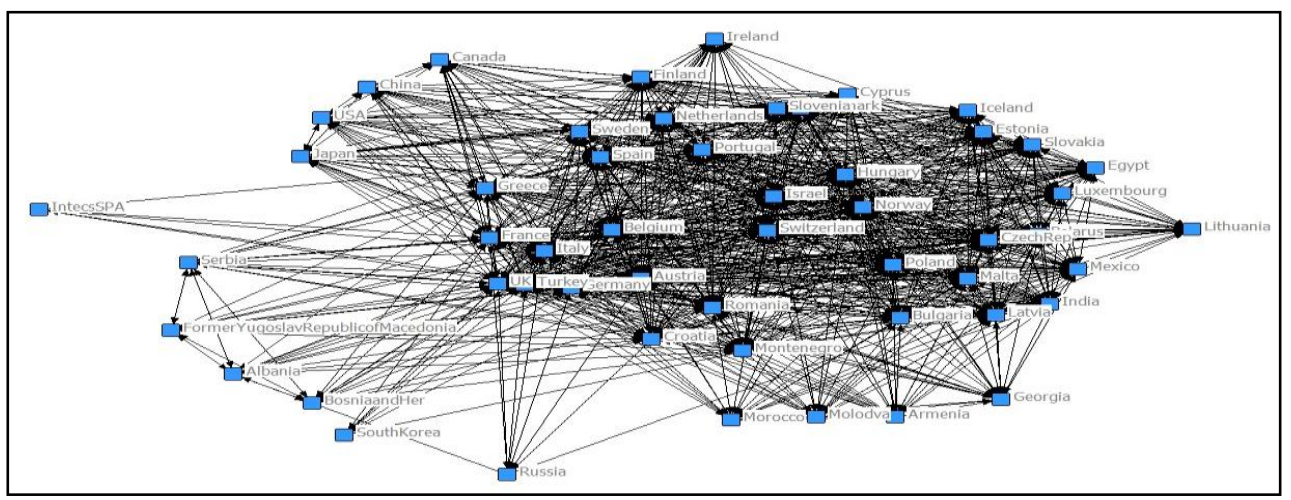

Figure: 3

SNA Map of ICT Projects in FP7 (Turkey and Germany are participants)

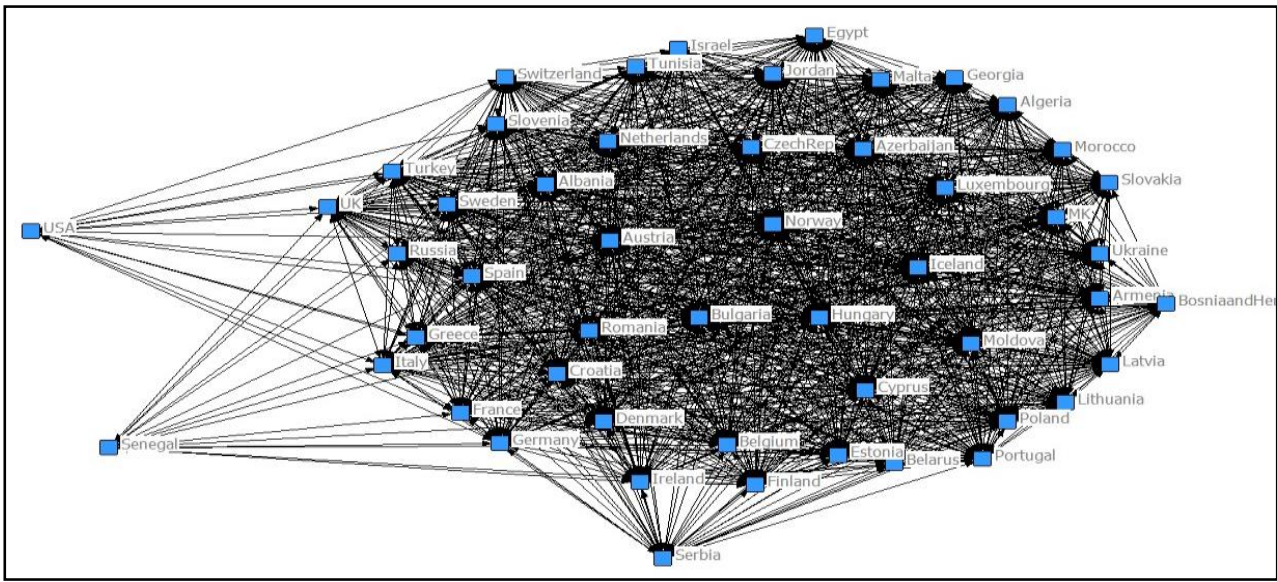

To further strengthen this proposition, graph metrics (centrality measures) are calculated and those for Turkey are shown in Table 5. The measurements for the degree centrality imply that the number of direct links of Turkey was 107 in FP5 but increased dramatically to 616 in FP6 with a slight decrease to 592 in FP7.

In terms of closeness centrality which is the length of their shortest paths, Turkey could not improve its position as the closeness centrality increased from 37 to 50 and to 52 in FP5, FP6 and FP7, respectively, meaning that the length of the links hat Turkey had increased. This finding is consistent with the position of Turkey in the network maps being at the outer circle of the network. 
Betweenness centrality which was 34.52 in FP5 decreased to 10.50 but tremendously increased to 97.65 in FP7. This implies that throughout FP5, 6 and 7, Turkey improved her role as an intermediary in the European research arena and thus her control of information enhanced. Eigenvector centrality depends both on the number and the quality of connections and shows the average centrality of all neighbors. As it can be seen from Table 5, Turkey's eigenvector centrality consistently increased from FP5 to FP6 to FP7 (0.296, 0.331, and 0.396 respectively).

Table: 5

Centrality Measures for Turkey in ICT Projects (with Germany Participant) in FP5, FP6 and FP7

\begin{tabular}{|c|c|c|c|}
\hline & FP5 & FP6 & FP7 \\
\hline Degree centrality & 107 & 616 & 592 \\
\hline Closeness centrality & 37 & 50 & 52 \\
\hline Betweenness centrality & 34.52 & 10.59 & 97.65 \\
\hline Eigenvector centrality & 0.296 & 0.331 & 0.396 \\
\hline
\end{tabular}

The results from the SNA analysis by the maps and the centrality measures depict that in the $5^{\text {th }}, 6^{\text {th }}$ and $7^{\text {th }}$ Framework Programmes ICT projects where Turkey and Germany collaborated, by means of transnational linkages in the social research networks, social capital in Turkey increased through the linking property of social capital.

\section{Conclusion}

For countries to cope with increasing competition and complexity in the global world, social capital which can be developed by participation in networks, is deemed valuable and is most desirable. Networks provide fertile grounds for breeding trust and shared values that reduce transaction and monitoring costs and enable knowledge transfer and innovation. Transnational linkages help increase social capital of a country by means of various kinds of interactions between economic agents in the networks. Economic agents incorporate knowledge by these transnational networks through the universality of scientific knowledge and recruit social capital in their country while they continue to pursue their self-interest.

This study investigates the linking social capital aspect and transnationality of academia through academic networks in ICT sector via European Framework Programme (FP5, FP6, FP7) projects in which i) Turkey is the coordinator of the project and Germany is a partner, ii) Germany is the coordinator of the project and Turkey is a partner, iii) Both Turkey and Germany are partners in the project.

The analysis of Turkish-German collaboration in ICT thematic area in the European Framework Programmes shows that Germany has been a very crucial partner for Turkey. ICT sector constituted the area in which Turkish and German actors cooperated the most. The results from the SNA analysis which investigated the (linking) social capital formation in Turkey by the maps and the centrality measures depict that in the $5^{\text {th }}, 6^{\text {th }}$ and $7^{\text {th }}$ Framework Programmes ICT projects where Turkey and Germany collaborated, social capital in Turkey increased through the linking property of social capital. This proves the proposition of this study that transnational linkages in networks provided the basis and 
opportunities for knowledge transfer and innovation networks, contributing to the formation of social capital in Turkey.

Based on the findings of this study which puts forward the absolute value of social capital formation in Turkey with specific focus in ICT projects and collaboration with Germany, further research aims to enhance the analysis to include the institutions in Turkey and Germany and to analyze in detail the social capital creation of these institutions individually through statistical testing.

\section{References}

Avnimelech, G. \& M. Teubal (2008), "From Direct Support of Business Sector R\&D/Innovation to Targeting Venture Capital/Private Equity: A Catching-Up Innovation And Technology Policy Life Cycle Perspective", Economics of Innovation and New Technology, 17(1-2), 153-172.

Annen, K, (2003), "Social capital, inclusive networks, and economic performance", Journal of Economic Behavior and Organization 50(4), 449-463.

Bilecen, B. \& G. Çatır \& A. Orhon (2015), "Turkish-German Transnational social Space: Stitching across Borders", Population, Space and Place, 21(3), 244-256.

Coe, N.M. \& T.G. Bunnell (2003), “Spatializing'knowledge communities: towards a conceptualization of transnational innovation networks", Global Networks, 4, 437-456.

Cooke, P. (1996), "The New Wave of Regional Innovation Networks: Analysis, Characteristics and Strategy", Small Business Economics, 8, 159-171.

Cordis (2017), Projects and Results, <http://cordis.europa.eu/projects/home_en.html>, 25.08.2017.

Dahal, G.R. \& K.P. Adhikari (2008), "Bridging, Linking, and Bonding Social Capital in Collective Action", Working Paper, CGIAR Systemwide Program on Collective Action and Property Rights (CAPRi), Working Paper No: 79, May.

Dhanaraj, C. \& A. Parkhe (2006), “Orchestrating Innovation Networks”, Academy of Management Review, 31(3), 659-669.

Frenken, K. (2000), “A complexity approach to innovation networks”, Research Policy, 29, 257-272.

Fukuyama, F. (1995), "Social capital and the global economy”, Foreign Affairs, 74(5), 89-103.

Glaeser, E.L. \& D. Laibson \& B. Sacerdote (2002), “An economic approach to social capital”, The Economic Journal, 112(483), 437-458.

Gülcan, Y. \& C. Aldemir (2017), "Analysis of historical roots and context of Turkish-German academic and scientific-innovative networks", in: International Innovation Networks and Knowledge Migration: The German-Turkish nexus, A. Pyka \& Y. Kustepeli \& D. Hartmann (eds.), New York, USA, 303-17.

Güler, H. \& O. Kara (2011), Enhancing Knowledge Spillovers through International R\&D Networking: The Case of Turkey's Participation in the $6^{\text {th }}$ EU Framework Programme, DRUID 2011, Innovation, Strategy, and Structure -Organizations, Institutions, Systems and Regions, Denmark.

Heller-Schuh, B. \& M. Barber \& L. Henriques \& M. Paier \& D. Pontikakis \& T. Scherngell \& G.A. Veltri \& M. Weber (2011), Analysis of Networks in European Framework Programmes (1984-2006), EUR 24759 EN Joint Research Centre Institute for Prospective Technological Studies. 
Henry, L. \& G. Mohan \& H. Yanacopulos (2004), "Networks as transnational agents of development", Third World Quarterly, 25(5), 839-855.

Icduygu, A. (2012), "50 Years after the Labour Recruitment Agreement with Germany: The Consequences of Emigration for Turkey", Perceptions, 17(2), 11-36.

Jacobs, J. (1965), The Death and Life of Great American Cities, London: Penguin Books.

Jöns, H. (2007), "Transnational mobility and the spaces of knowledge production: a comparison of global patterns, motivations and collaborations in different academic fields", Social Geography, 2, 97-114.

Knack, S. \& P. Keefer (1997), "Does social capital have an economic payoff? A cross-country investigation", The Quarterly journal of economics, 112(4), 1251-1288.

Kustepeli, Y. \& C. Balkır \& S. Akgungor \& Y. Gulcan \& M.A. Beyzatlar \& S. Gunduz (2013), "Turkish-German economic relations via foreign direct investment and patents", Journal of Entrepreneurship and Innovation Management, 1(2), 23-50.

Lin, N. (1999), "Building a network theory of social capital”, Connections, 22(1), 28-51.

Mones, R.A. \& R.A. Bautista \& M.R. Rola (2015), "Promoting lifelong learning: what marketers can learn from social capital theory", in: Third International Conference on Asian Studies, T. Endo (ed.), Niigata: International Center for Research and Development, Niigata, Japan, 20-21 June 2015, 124-130.

Poortinga, W. (2012), "Community resilience and health: The role of bonding, bridging, and linking aspects of social capital", Health and Place, 18(2), 286-295.

Putnam, R.D. (1993), “The prosperous community”, The American Prospect, 4(13), 35-42.

Pyka, A. \& Y. Kustepeli \& C. Balkır \& D. Hartmann (2017), "Introduction”, in: International Innovation Networks and Knowledge Migration: The German-Turkish nexus, A. Pyka \& Y. Kustepeli \& D. Hartmann (eds.), New York, USA, 1-12.

Pyka, A. \& A. Scharnhorst (2009), Innovation Networks: New Approaches in Modelling and Analyzing, Berlin: Springer-Verlag.

Pyka, A. \& T. Buchmann (2011), "Innovation networks", in: Handbook on the Theory of the Firm, J. Krafft \& M. Dietrich (eds.), Cheltenham: Edward Elgar, 466-483.

Routledge, B.R. \& J. Von Amsberg (2003), "Social capital and growth", Journal of Monetary Economics, 50(1), 167-193.

Sabatini, F. (2009), "Social capital as social networks: A new framework for measurement and an empirical analysis of its determinants and consequences", The Journal of SocioEconomics, 38(3), 429-442.

TGIN (2014), "Knowledge Transfer in Turkish-German Innovation Networks in the Context of European Integration", IntenC Programme Project funded by TUBITAK, August 2011 August 2014.

Tödtling, F. (1999), "Innovation Networks, Collective Learning, and Industrial Policy in Regions of Europe”, European Planning Studies, 7(6), 693-97.

Wang, C.T.L. \& R.I. Hosoki (2016), "From Global to Local Transnational Linkages, Global Influences, and Taiwan's Environmental NGOs", Sociological Perspectives, 59(3), 56158.

Woolcock, M. (1998), "Social capital and economic development: Toward a theoretical synthesis and policy framework", Theory and Society, 27(2), 151-208. 
Kuştepeli, Y. \& S. Akgüngör \& Y. Gülcan (2019), "Social Capital and Turkish-German Academic Linkages", Sosyoekonomi, Vol. 27(39), 205-222.

Zander, I. (1999), “How do you mean 'global'? An empirical investigation of innovation networks in the multinational corporation", Research Policy, 28, 195-213. 